\title{
Research on economic life of building based on the principle of equipment renewal
}

\author{
Wang Jianbin ${ }^{1, a}$, Wang Ruiying ${ }^{2, b}$ \\ School of management, Xi'an University of Architecture And Technology, Xi'an 710055 \\ axcfengxinzi@163.com , b879337275@qq.com
}

Keywords: construction life; urbanization; equipment renewal; economic life

\begin{abstract}
Along with the rapid development of economy, the pace of China's urbanization is increased heavily.Due to the lack of long-term planning,the demolition of constructions phenomenon is serious, most of the buildings have been removing that not reach the design using age, resulting in a great deal of constructions trash, causing the environment adverse effects, and leading to the waste of resources.This paper analyzes the factors of the house life, and makes a simple exploration of the economic life of the house by the principle of equipment renewal.
\end{abstract}

\section{Introduction}

Every year,the area of 18 million square meter buildings will be constructed almost in China, and consuming nearly the percent of 39 building materials of the world.However , the buildings only have been preserving 25-30 years ${ }^{[1]}$.According to the investigation by Chongqing University Professor Liu Guiwen ${ }^{[2]}$ that based on Chongqing Jiang Bei District and Da Dukou District of the demolition of constructions, the constructions average life is only 38 years.And its quality factors have no significant correlation to the shorter life.On the contrary, political factors, interest driven, the scarcity of land and other factors are closely related, which is thought-provoking.

Economic life counting means that the most reasonable service life through economic field ,which from the starting of the investment decision-making stage.Constructions will be degenerated gradually with the long time use.It is unreasonable that continue to use old buildings, because the cost of repairing,maintenance, renewal will be rising. Generally speaking,annual asset recovery cost curve is gradually decreasing,annual use of the cost curve is increasing year by year.The equivalent annual cost curve is determined by the annual asset recovery cost curve and the annual cost curve,which decline firstly and then rise later, the time of concave point just is economic life.

\section{Impact factor analysis of building life}

\subsection{Economic development is a catalyst for the renewal of residential housing concept}

"The economic base determines the superstructure".In the low level of economic development, people's material life is not adequate, solving food and clothing shortage problem is the top priority for many people.After the economic level has been greatly improved,most people will seek higher levels of mental and psychological satisfaction.

Between 1952 and 1978, annual average growth rate of Total retail sales of social consumer goods is only $5.4 \%$,also of the national consumption level is also at a low level of $2.3 \%$.Obviously, with the improvement of material living standards, people's consumption habits, consumption patterns and consumer psychology will be changed.

From the perspective of constructions, residential pattern is closely related to the changes of economic and living habits .The changes of residence concept, the improvement of construction level, the innovation of building materials, and the innovation development of architectural landscape are directly linked with the economic level.With the development of economy, people's living concept has been updated.This directly led to the demolition of houses, reconstruction and renovation and other consequences.And also have a direct impact on the house life. 


\subsection{Contradiction between man and land cause adverse impact on the building life}

At present, our country is in the stage of rapid development of urbanization. With the development of the social economy and population increase, coupled with the growing number of idle rural labor force into town. The contradiction between population and land in cities and towns is becoming more and more prominent.

According to the sixth national census data of China,the proportion of urban population in China is $49.71 \%$,compared with the Fifth National Census,the urban population quantity Rose $13.46 \%$.Because the urban area has not significantly expanded,construction land supply tension and low-rise buildings have been unable to meet the needs of social development,people have to build high-rise buildings.So people remove old houses to get the land,which shorten the building life and produce a great deal construction waste.

\subsection{Government policies on the impact of residential life}

From 1980 to today,China's real estate market have been gradually developing,we proposed the housing commercialization view firstly in 1978. Shen Zhen government sell residential land by means of transferring state-owned land public bidding firstly in 1987.At the beginning of the 1990s,start to establish housing accumulation fund system and reform Real estate cosmically.Since 2003,many big city's housing prices have risen significantly.A number of regulatory policy come into operation in order to control high housing prices. The contradiction between house and land is getting more and more worse during these time.

Additionally,with accelerating the transformation of the old city,many old city buildings are changed into construction waste.Due to the lack of long-term planning of the government and some city layout policies are inconstant,the phenomenon of construction and removal is insane. Some officials like constructing image project so that shorten house life.

\subsection{The influence of the building's own factor on the life}

The building's self factors have a major impact on its life,such as construction technology,decoration quality,geological conditions,hydrological condition and so on.During initial stages for reform and opening-up,many places constructed many fast food style houses in order to improve the quality of living.Bad housing quality have a bad influence on life.Some barbaric act of decoration for the quality of housing has buried a security risk.Different construction methods, as well as different building materials have great influence on the life of the building.

Table1 Life of different structures ${ }^{[3]}$

\begin{tabular}{|c|c|c|c|}
\hline No. & Type & Construction Life & (year) \\
\hline 1 & Steel structure & 55 & \\
\hline 2 & Steel concrete structure & 60 & \\
\hline 3 & Brick concrete structure & 50 & \\
\hline 4 & post and panel structure & 30 & \\
\hline 5 & Simple structure & 10 & \\
\hline
\end{tabular}

\section{Negative effect analysis of ephemeral buildings}

\subsection{Threat of environmental resources}

The blind demolition of building lead to the generation of a large number of construction waste.Removing 10000 square meters old buildings will produce $7000 \sim 12000$ tons of construction waste.Much data indicate that construction waste has accounted for about 35\% of the total urban waste annual and brought a huge negative impact on China and the world environment.Construction activity will consume a large amount of steel, cement and sand, which is creasing resource pressure further.

\subsection{The deficiency of belongingness}

Old buildings carry the old memories,the emergence of short-lived buildings hurt people's feelings,especially for old people.Due to demolition,many older people are forced to move away from their familiar home, to different places to live, the old neighborhood relationship is destroyed, 
and because of the barrier of tall buildings, the new neighborhood is difficult to build, it is easy to create a sense of lacking belonging and cause social disharmony factors.

\section{An empirical analysis of the economic life of houses}

One house acquisition cost is 300000, other annual cost (including water, electricity, gas, property management fees, maintenance fees, etc.)As shown in the table of 4-1.The depreciation period of the house is 35 years. The net residual value is 9000 yuan and the computing cycle is 5 years.

\subsection{The static analysis method of house economic life}

The static analysis method of house economic life means that to ignore the time value of money.The formula ${ }^{[4]}$ for calculating the annual equivalent cost is that as follows:

$$
A C_{n}=\frac{P-L_{n}}{n}+\frac{1}{n} \sum_{j=1}^{n} C_{j}
$$

Explanation:n-the house life, $n=20 ; j$-the use year of house, $\mathrm{j}$ values range from 1 to $\mathrm{n},{ }^{A C_{n}}-\mathrm{n}$ years of housing equal annual total cost, $\mathrm{P}$ - the acquisition cost of house, ${ }^{C_{j}}$ - $\operatorname{cost}$ of $\mathrm{j}$ year, ${ }_{n}$ —in the $n$ years of the net residual value.

During the use of housing,the lowest total annual cost of the matching time is the economic life of housing.Beyond the housing's economic life, if the housing structure structural reliability and residential comfort are still meet the use requirements, you can continue to use it, but it is unreasonable from the economic point of view.

Table2 statistical data table

\begin{tabular}{cccccccc}
\hline year & 1 & 2 & 3 & 4 & 5 & 6 & 7 \\
\hline $\begin{array}{c}\text { operating } \\
\text { costs }\end{array}$ & 50000 & 60000 & 70000 & 90000 & 110000 & 150000 & 175000 \\
$\begin{array}{c}\text { at the end of } \\
\text { n scrap value }\end{array}$ & 150000 & 75000 & 37500 & 18750 & 14500 & 9000 & 9000 \\
\hline
\end{tabular}

\subsection{Annual equal total cost}

By formula (1) we can know that annual equal total cost $A C_{n}$ equals the annual equal asset recovery cost $\frac{P-L_{n}}{n}$ plus annual equal operating costs $\frac{1}{n} \sum_{j=1}^{n} C_{j}$.The $A C_{n}$ are shown in the following table.

Table $3 A C_{n}$ data table

\begin{tabular}{cccc}
\hline Period & $\frac{P-L_{n}}{n}$ & $\frac{1}{n} \sum_{j=1}^{n} C_{j}$ & $A C_{n}$ \\
\hline 1 & 150000 & 50000 & 200000 \\
2 & 112500 & 55000 & 167500 \\
3 & 87500 & 60000 & 147500 \\
4 & 70312.5 & 67500 & 137812.5 \\
5 & 57100 & 76000 & 133100 \\
6 & 48500 & 88333.3 & 136833.3 \\
7 & 41571.4 & 100714.2 & 142285.7 \\
\hline
\end{tabular}

From table 3,the lowest $A C_{n}$ is $¥ 133100$,so the economic life of the housing is 25 years. 


\section{Conclusion}

Because the phenomenon of "short lived architecture" ${ }^{[5]}$ in China would cause the threat of environmental and resources deficiency of belongingness, which should not be ignored.Due to government planning dislocation, construction quality problems and other reasons, the most house economic life is about 25 years. Therefore, it should improve the level of government planning and strengthen market supervision to ensure the constructions quality and extend the life.

\section{References}

[1] Ouyang Jiantao.Study on the life cycle of urban residence in China.2007 (6): [D]. (): 15-46

[2] Liu Guiwen, Xu Kexi.Removed 2012 development research study on the life of [J]. city building 2012 (10): 109-112

[3] Shen Jinzhen. "Short lived architecture" can not be on the construction of urban development.2008 [J]. (2): 117

[4] Liu Xiaojun.Engineering economics[M].(1):242-246.China Construction Industry Press.2008

[5] Hu Mingli,Wu Qiong.Analysis of the resource,energy and environmental problems caused by short lived building [J]. building energy saving.2008 (1): 70-74 